U.S. DEPARTMENT OF THE INTERIOR

U.S. GEOLOGICAL SURVEY

\title{
INTERPRETIVE GEOPHYSICAL FAULT MAP ACROSS THE CENTRAL BLOCK OF YUCCA MOUNTAIN, NEVADA
}

\author{
By
}

\section{D.A. Ponce}

1996

\section{Open-File Report 96-285 \\ Prepared in cooperation with the \\ Nevada Operations Office \\ U.S. Department of Energy \\ (Interagency Agreement DE-AI08-92NV10874)}

This report is preliminary and has not been reviewed for conformity with U.S. Geological Survey editorial standards or with the North American Stratigraphic Code. Any use of trade, firm, or product names is for descriptive purposes only and does not imply endorsement by the U.S. Government.

\section{Menlo Park, California}


Copies of this Open-File Report

may be purchased from

USGS-Information Services

Box 25286, Bldg. 810, Federal Center

Denver, CO 80225

PREPAYMENT IS REQUIRED

Price information will be published

in the monthly listing

New Publications of the Geological Survey

FOR ADDITIONAL ORDERING INFORMATION

CALL: (303) 202-4200 
U.S. DEPARTMENT OF THE INTERIOR

U.S. GEOLOGICAL SURVEY

INTERPRETIVE GEOPHYSICAL FAULT MAP ACROSS THE CENTRAL BLOCK OF YUCCA MOUNTAIN, NEVADA

$B y$

D.A. Ponce ${ }^{1}$

GEOLOGICAL SURVEY OPEN-FILE REPORT 96-285

1 U.S. Geological Survey, Menlo Park, CA 


\section{CONTENTS}

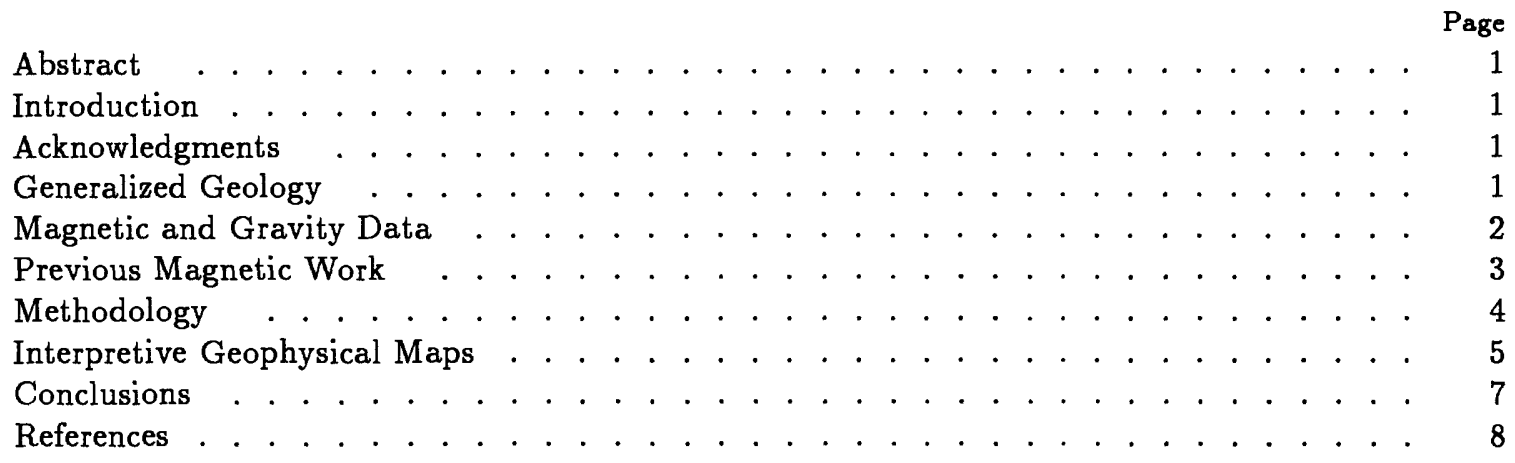

\section{TABLES}

2. Physical properties of rock units used in the fault model

\section{ILLUSTRATIONS}

FIGURE1. Index map of study area . . . . . . . . . . . . . . . . . . . . . . . . 13

2. Theoretical fault model across a normal fault . . . . . . . . . . . . . . . 14

Plate 1. Location of central block traverses . . . . . . . . . . . . . . . in pocket

2. Interpretive geophysical fault map . . . . . . . . . . . . . . . . . in pocket

3. Interpretive geophysical fault map-continued . . . . . . . . . . . . in pocket

4. Ground magnetic anomaly map . . . . . . . . . . . . . . . . . . . in pocket 


\begin{abstract}
Geophysical data collected along 29 traverses across the central block of Yucca Mountain in southwest Nevada reveal anomalies associated with known faults and indicate a number of possible concealed faults beneath the eastern flank of Yucca Mountain. Geophysical interpretations indicate that Midway Valley is characterized by several known and previously unknown faults, that the existence of the Yucca Wash fault is equivocal, and that the central part of the eastern flank of Yucca Mountain is characterized by numerous low-amplitude anomalies that probably reflect numerous small-scale faults. Gravity and magnetic data also reveal several large-amplitude anomalies that reflect larger-scale faulting along the margins of the central block.
\end{abstract}

\title{
INTRODUCTION
}

Geophysical investigations of the central block of Yucca Mountain are part of an effort to help characterize faulting near a potential nuclear waste repository at Yucca Mountain. The study area is about $130 \mathrm{~km}$ northwest of Las Vegas in the southwest quadrant of the Nevada Test Site (NTS) and is bounded by Crater Flat to the west, Yucca Wash to the north, and Jackass Flats to the east (fig. 1). Geophysical anomalies are interpreted in terms of possible faulting along 29 detailed ground magnetic traverses and 13 detailed gravity traverses across the central block of Yucca Mountain and vicinity.

\section{ACKNOWLEDGMENTS}

R.F. Sikora, V.E. Langenheim, R.L. Morin, C.W. Roberts, S.C. Kuehn, P.F. Halvorson, S.L. Snyder, and R.V. Allen of the U.S. Geological Survey assisted in the gravity, magnetic, or location data collection and reduction.

\section{GENERALIZED GEOLOGY}

The study area is underlain by Precambrian and Paleozoic rocks, a series of Miocene ash-flow tuffs interbedded with relatively thin ash-fall and re-worked tuffs, and late Tertiary and Quaternary surficial deposits (table 1). Pre-Cenozoic sedimentary and metamorphic rocks in the study area are predominantly limestone and dolomite, with lesser amounts of argillite, quartzite, and marble (U.S. Geological Survey, 1984).

Cenozoic volcanic units at Yucca Mountain include older ash-flow tuffs, Lithic Ridge Tuff, Crater Flat Group, Calico Hills Formation, Paintbrush Group, and Timber Mountain Group 
(Sawyer and others, 1994). The Crater Flat Group is composed of the Tram, Bullfrog, and Prow Pass Tuffs; the Paintbrush Group is composed of the Topopah Spring, Pah Canyon, Yucca Mountain, and Tiva Canyon Tuffs; and the Timber Mountain Group is composed of the Rainier Mesa and Ammonia Tanks Tuffs. The Volcanics of Fortymile Canyon, which are younger than the tuff sequence exposed at Yucca Mountain, occur northeast of Yucca Wash.

\section{MAGNETIC AND GRAVITY DATA}

Detailed ground magnetic data are summarized along 29 profiles across the central block of Yucca Mountain (fig. 1). Ground magnetic data were collected with the sensor at $2.4 \mathrm{~m}$ above the surface with a maximum station spacing of about 20 paces or about $18 \mathrm{~m}$ and minimum spacing of 1 pace or about $1 \mathrm{~m}$. Locations of magnetic stations between surveyed points were determined by interpolation using the number of paces and the distance between surveyed points. Geometrics proton precession magnetometers accurate to about $1 \mathrm{nT}$ (nanotesla) were used to collect the data. A base-station magnetometer was used or a temporary base along the traverse was periodically re-occupied during the survey to make corrections for diurnal variations of the Earth's magnetic field. The base-station magnetometer was located near the center of the study area in the southern part of Midway Valley and readings were typically recorded at about 1 -minute intervals.

Results of detailed gravity data are reported here from the 13 lines that were collected by the U.S. Geological Survey which includes lines AR, LYR, WT-2, G1 through G4, and YA through YF (fig. 1). Gravity data along regional seismic lines $2 R E G$ and $3 R E G$ (fig. 1 and pl. 1) were presented by Brocher and others (1996). Gravity data along high-resolution seismic lines 1 through 12 across the central block were briefly reported on by Feighner and others (Lawrence Berkeley National Laboratory, written commun., 1995; Majer and others, 1996).

Gravity data were reduced using the Geodetic Reference System of 1967 (International Union of Geodesy and Geophysics, 1971) and referenced to the International Gravity Standardization Net 1971 gravity datum (Morelli, 1974, p. 18). Gravity data were reduced to complete Bouguer anomalies for reduction densities of 2.67 and $2.00 \mathrm{~g} / \mathrm{cm}^{3}$ and include earthtide, instrument drift, free-air, Bouguer, latitude, earth-curvature, and terrain corrections. Terrain corrections were computed using a three-part process to maximize their accuracy. Because topographic maps or digital elevation models are not detailed enough for the accuracy desired, corrections nearest the station from 0 to $68 \mathrm{~m}$ (Hayford-Bowie zones $\mathrm{A}$ and $\mathrm{B}$, Swick, 1942) were manually computed in the field. Corrections from a radial distance of 68 to $540 \mathrm{~m}$ (zones $\mathrm{C}$ and $\mathrm{D}$ ) were manually computed by averaging the terrain surrounding the station using a template and topographic maps at a scale of $1: 24,000$ or greater. Finally, corrections from 0.54 to $166.7 \mathrm{~km}$ (zones $\mathrm{E}$ through $\mathrm{O}$ ) were computer calculated using a digital elevation model derived from 1:250,000-scale topographic maps and a procedure by 
Plouff (1977).

Station locations for Midway Valley lines G1 through G4, Yucca Wash lines YA through $\mathrm{YF}$, and central block lines 1 through 12 were surveyed by Raytheon Services Nevada. Stations for Antler Ridge line AR, Live Yucca Ridge line LYR, and Jet Ridge lines JR1 and JR2 were surveyed by the U.S. Geological Survey geophysical field party using an electronic distance-measurement device or a Global Positioning System (GPS). Locations for the WT2 Wash line WT-2 were surveyed using an electronic distance-measurement device. Station locations for regional seismic reflection lines 2 and 3 (2REG and $3 R E G$ ) were surveyed by Extreme Surveys, Inc. In general, station elevations are accurate to about $0.1 \mathrm{~m}$ and horizontal locations were accurate to about $1 \mathrm{~m}$. Station locations were spaced at intervals of about $50 \mathrm{~m}$ for lines G1 through G4, YA through YF, WT-2, LYR, JR1, JR2, and 10; $25 \mathrm{~m}$ for lines AR, 2REG, and 3REG; $12 \mathrm{~m}$ for lines 1 through 9 and 11 ; and $3 \mathrm{~m}$ for line 12 .

\section{PREVIOUS MAGNETIC WORK}

A large body of previous work exists describing magnetic anomalies and the magnetic properties of the various volcanic rock units of the Nevada Test Site and vicinity. Bath (1968) established the gross relationships between magnetic anomalies and many of the exposed volcanic units at the Nevada Test Site and then began to use these data to map these units where not exposed and to infer geologic structure. Bath (1968) also reported the polarity and magnetization of these rocks which included the Topopah Spring Tuff and various formations of the Timber Mountain Group. Additional magnetic properties of various volcanic rocks were described by Bath and Jahren (1984) and Rosenbaum and Snyder (1985). A summary of the physical properties of the rock units that comprise the stratigraphic sequence at Yucca Mountain was compiled by Ponce and Langenheim (1994) and is shown in table 2.

Aeromagnetic studies by Kane and Bracken (1983) and Bath and Jahren (1984) have shown that many of the north-trending linear magnetic anomalies at Yucca Mountain are caused by vertical offset of the normally polarized Topopah Spring Tuff. The Topopah Spring Tuff is moderately to highly magnetic, relatively thick, and exposed or buried near the surface at Yucca Mountain. Thus, it is one of the major magnetic anomaly-producing units at Yucca Mountain. These studies show that north-trending and en echelon aeromagnetic anomalies correlate to major mapped down-to-the-west normal faults at Yucca Mountain including the Solitario Canyon, Bow Ridge, and Paintbrush Canyon faults (fig. 1). Major anomalies in the northeast part of the study area also correlate to outcrops of the Topopah Spring Tuff.

Bath and Jahren (1984) suggested that an east-trending magnetic anomaly across the northern part of Yucca Mountain may be related to altered argillite of the Eleana Formation at depth, similar to that exposed at Calico Hills. At Calico Hills, the argillite is normally magnetized and strongly magnetic with an average total magnetization of $3.89 \mathrm{~A} / \mathrm{m}$ for 123 samples. Three-dimensional modeling of the long-wavelength nature of this feature suggests 
that its source is about 2 to $2.5 \mathrm{~km}$ below the surface (Bath and Jahren, 1984).

Bath and Jahren (1984) described an aeromagnetic high on the west flank of Yucca mountain detected by a north-south survey that was not detected by an earlier east-west survey with similar spacing and height above terrain. They suggested that the anomaly may be caused by several factors or a combination of factors such as terrain, proximity to the magnetic high caused by the upthrown block of the Solitario Canyon fault, increase in magnetization of the Topopah Spring Tuff, or less likely, a small intrusive body.

\section{METHODOLOGY}

A comparison of gravity and magnetic profiles to geologic and structural information, primarily displayed on the geologic map of Yucca Mountain by Scott and Bonk (1984), yields information on the geophysical signature of known faults, fractures, structures, and of the various volcanic formations at Yucca Mountain. The geophysical signatures of know $n$ features combined with theoretical signatures or modeling can then be used to infer geologic features.

The magnetic effect of a fault is complex due to the inherent directional nature of rock magnetism and the fact that total magnetization is composed of induced and remanent components. The induced magnetization is in the direction of the Earth's present magnetic field, whereas the remanent magnetization can be in any direction. The gravity and magnetic effects of infinite vertical and $70^{\circ}$-dip down-to-the-west faults for the volcanic stratigraphy at Yucca Mountain are shown in figures $2 \mathrm{a}$ and $2 \mathrm{~b}$, respectively. The models are based on the averaged physical properties and known thicknesses of tuff units at Yucca Mountain shown in tables 1 and 2 . The shape and amplitude of the anomalies are also applicable for down-tothe-east faults by simple rotation of $180^{\circ}$ about the center point of the horizontal axis. An important result of these models is that the overriding or dominant magnetic signature of a normal fault at Yucca Mountain and vicinity is caused by the moderately magnetized and relatively thick Topopah Spring Tuff (fig $2 \mathrm{a}$ ). In contrast to the magnetic effect of a fault the gravity effect of a fault is much simpler with a gravity low over the downthrown block and a gravity high over the upthrown block.

Although down-to-the-west normal faults play a dominant role in the style of faulting at Yucca Mountain, a fault-zone model may be important for some faults. The fault-zone model is characterized by both gravity and magnetic lows, exemplified by the gravity and magnetic signatures over the Ghost Dance fault along Antler and Live Yucca Ridges described by Ponce and Langenheim (1995, figs. $3 \mathrm{~b}$ and $3 \mathrm{~d}$ ). The gravity low may result from a decrease in density caused by brecciation along the fault zone, and the magnetic low may result from a loss of magnetization caused by alteration.

These two geophysical fault models were used to infer faulting on the eastern flank of Yucca Mountain: a down-to-the-west fault model and a fault-zone model. For north 
trending faults along east-west profiles, the down-to-the-west fault model is characterized by a magnetic low over the downthrown block and a magnetic high over the upthrown block as shown in figure 2. Similarly, for east-trending faults along north-south profiles, the down-to-the-north fault model is characterized by a magnetic low of higher amplitude over the downthrown block and a magnetic high of lower amplitude over the upthrown block as compared to north-trending faults. In slight contrast, gravity data across normal faults are characterized by a gravity low on the downthrown block and a gravity high over the upthrown block.

\section{INTERPRETIVE GEOPHYSICAL MAPS}

Interpretations are summarized here from previously published reports of studies of Midway Valley and Yucca Wash (Ponce and Langenheim, 1994), Ghost Dance and Solitario Canyon faults (Ponce and Langenheim, 1995), central block area (Ponce and others, 1995), and regional seismic reflection lines 2 and 3 across Bare Mountain, Crater Flat, and Yucca Mountain (Langenheim and Ponce, 1995; Brocher and others, 1996). In addition, the profiles and results for the remaining nine unpublished magnetic lines which include lines $1,6,7$, $7 \mathrm{~A}, 8,9,12$, JR1, and JR2 across the central block are presented. These 29 traverses, some 90-line-km within the study area, represent all the data collected along surveyed traverses during the years 1993-95.

Plates 2 and 3 are interpretive geophysical fault maps of the central block of Yucca Mountain depicting possible fault locations or changes in physical properties in areal view. Possible fault locations were inferred along traverses across the central block of Yucca Mountain using gravity, ground magnetic, aeromagnetic, and geologic data. As an interpretive aid ground magnetic data were adjusted to a common datum and are also displayed as a color contour map (pl. 4) with a grid interval of $25 \mathrm{~m}$ and a contour interval of $20 \mathrm{nT}$.

In general, most locations of possible faulting cannot be traced from one profile to another, primarily due to severe magnetic terrain effects along the east flank of Yucca Mountain. Furthermore, many profiles are parallel to geologic structure, widely-spaced apart, and most of the faulting on the eastern flank of Yucca Mountain is small-scale with small vertical offsets. However, major block-bounding faults or those with a characteristic signature can be traced from one profile to another such as the Paintbrush Canyon and Bow Ridge faults.

Along the margins of Midway Valley, gravity and magnetic data across traverses G1 through G4 (fig. 1) reveal prominent anomalies associated with the Bow Ridge and Paintbrush Canyon faults. The Paintbrush Canyon fault is one of the largest gravity and magnetic highs at Yucca Mountain and vicinity. These faults are easily traced from one profile to another and extend the entire length of Midway Valley (pls. 2 and 4). Gravity and magnetic modeling indicate vertical offsets of about 100 to $200 \mathrm{~m}$ for the Bow Ridge fault and about 200 to $400 \mathrm{~m}$ for the Paintbrush Canyon fault (Ponce and Langenheim, 1994). 
In the central part of Midway Valley, gravity and magnetic data reveal a number of possible small-scale concealed faults. Two of these faults, defined by a gravity and magnetic high, may reflect a horst-like feature that has been referred to as the Midway Valley feature (Ponce, 1993; Ponce and others, 1993). This geophysical anomaly can also be modeled as two down-to-the-west faults with rotated east-dipping strata (Ponce and Langenheim, 1994). In either case, gravity and magnetic modeling indicate vertical offsets of about $75 \mathrm{~m}$ (Ponce and Langenheim, 1994).

In addition, other faults can be delineated in Midway Valley, including a concealed fault on the east side of Exile Hill (fig. 1, pls. 2 and 4). Although the spacing between profiles in Midway Valley ranges from about $1 / 2$ to $1 \mathrm{~km}$, magnetic anomalies can be easily traced because magnetic terrain effects are minimized by low topographic relief and high frequency information is attenuated by alluvial cover (Ponce and Langenheim, 1994). These data provide more accurate locations for some of the faults shown on Scott and Bonk's (1984) geologic map (which were inferred from aeromagnetic data) and show that the concealed Midway Valley fault extends along the entire length of the valley.

Gravity and magnetic profiles YA through YE across Yucca Wash, spaced about $1.5 \mathrm{~km}$ apart, do not indicate any major vertical offsets along the postulated Yucca Wash fault but also do not preclude its existence. Profile lines YF and 7 trend approximately SSE along the wash, are nearly coincident, and yield almost identical magnetic profiles (fig. 1, pl. 3). Two parallel lines offset $100 \mathrm{~m}$ to either side of YF (not shown) also yield similar results and reflect the three-dimensional nature of the magnetic anomalies. A broad magnetic high near the intersection of lines YF and YC (pls. 3 and 4) correlates with an aeromagnetic high over Isolation Ridge and has a causative depth of about $500 \mathrm{~m}$ or less. The source of this anomaly may be rhyolite lava of the Calico Hills Formation, or more likely, the Topopah Spring Tuff. Because this anomaly occurs at the same location along the offset parallel lines, little or no horizontal offset may be indicated along the Yucca Wash fault. (See Ponce and Langenheim, 1994).

East-trending geophysical profiles across the eastern flank of Yucca Mountain are spaced about 0.1 to over $1 \mathrm{~km}$ apart. Detailed gravity as well as magnetic data were collected along lines AR and LYR (fig. 1) and were obtained to get a better understanding of the character of the Ghost Dance fault. Lines AR and LYR are characterized by numerous small-amplitude gravity and magnetic anomalies that probably reflect small-scale faulting. In particular, the Ghost Dance fault is associated with a gravity low of about $0.2 \mathrm{mGal}$ and a magnetic low of about 75 nanoteslas ( $\mathrm{nT}$ ). Gravity data suggest that the fault zone may be 100 to $200 \mathrm{~m}$ wide, whereas the magnetic anomaly spans a width of about $80 \mathrm{~m}$ (Ponce and Langenheim, 1994). Gravity data along lines AR and LYR indicate a vertical offset of about $20 \mathrm{~m}$ for the Ghost Dance Fault which is consistent with geologic data that indicate about $35 \mathrm{~m}$ of vertical offset near the southern edge of the potential repository (Spengler and others, 1993; 1994). Although other lines cross the Ghost Dance fault (fig. 1), severe magnetic terrain effects mask the signature of the fault along these lines. In fact, Ponce and others (1995) 
showed that magnetic terrain effects along the eastern flank of Yucca Mountain can reach up to about 150 to $200 \mathrm{nT}$ along some parts of lines 3 and 4 . These terrain-induced anomalies are pronounced in the vicinity of the Ghost Dance fault because the traverse is located at a bend in a wash below steep canyon walls (pls. 2 and 3). The location of the Ghost Dance fault along regional seismic line 2(2REG) can be delimited (pl. 2), whereas its location along line 3REG is equivocal.

North-trending magnetic profiles along the western and eastern flanks of Yucca Mountain are spaced about 1 to $2 \mathrm{~km}$ apart. These lines provide important information to level the magnetic datums for all the profiles but provide little geologic information because they parallel the structural trends at Yucca Mountain and have severe magnetic terrain effects. Along line 5, south of line LYR, magnetic data are smooth ( $\mathrm{pl}$. 3), whereas, north of line LYR, the data fluctuate rapidly and appear as a string of pearls in contour form (pl. 4). This change in character correlates with a down-to-the-north fault mapped along the crest of Yucca Mountain (Scott and Bonk, 1984). A similar change in magnetic character can also be observed along the northernmost parts of line 8 in the central part of the study area (pl. 4) Both these changes are related to a caprock unit of the uppermost part of the Tiva Canyon Formation (Scott and Bonk, 1984). The magnetic signature of this unit suggests that it is moderately to strongly magnetic.

\section{CONCLUSIONS}

Magnetic data along 29 traverses across the central block of Yucca Mountain and gravity data along 13 of these traverses reveal that Midway Valley is characterized by several known and previously unknown faults, that the existence of the Yucca Wash fault is equivocal, and that the central part of the eastern flank of Yucca Mountain is characterized by numerous low-amplitude anomalies that probably reflect numerous small-scale faults. Gravity and magnetic data also reveal several large-amplitude anomalies that correlate to larger-scale and mapped faults along the margins of the central block.

These geophysical studies show that they are useful for delineating major faults at Yucca Mountain such as the Solitario Canyon, Bow Ridge, and Paintbrush Canyon faults and minor faults such as the Midway Valley and the Ghost Dance faults along the eastern flank of Yucca Mountain. Additional detailed geophysical data and interpretations along carefully chosen traverses could provide additional information on the nature and extent of faulting in Yucca Mountain and vicinity. 


\section{REFERENCES}

Bath, G.D., 1968, Aeromagnetic anomalies related to remanent magnetism in volcanic rock, Nevada Test Site, in Eckel, E.B., ed., Nevada Test Site: Geological Society of America Memoir 110, p. 135-146.

Bath, G.D., and Jahren, C.E., 1984, Interpretations of magnetic anomalies at a potential repository site located in the Yucca Mountain area, Nevada Test Site: U.S. Geological Survey Open-File Report 84-120, 40 p. (NNA.870323.0194)

Brocher, T.M., Hart, P.E., Hunter, W. Clay, and Langenheim, V.E., 1996, Hybrid-source seismic reflection profiling across Yucca Mountain, Nevada: Regional lines 2 and 3: U.S. Geological Survey Open-File Report 96-28, 110 p.

Frizzell, V.A., and Shulters, Jacqueline, 1990, Geologic map of the Nevada Test Site, southern Nevada: U.S. Geological Survey Miscellaneous Investigations Series Map I-2046, scale $1: 100,000$.

International Union of Geodesy and Geophysics, 1971, Geodetic Reference System 1967: International Association of Geodesy Special Publication no. 3, 116 p. (NNA.901127.0202)

Kane, M.F., and Bracken, R.E., 1983, Aeromagnetic map of Yucca Mountain and surrounding regions, southwest Nevada: U.S. Geological Survey Open-File Report 83-616, 19 p., $1: 48,000$.

Langenheim, V.E., and Ponce, D.A., 1995, Ground magnetic studies along a regional seismicreflection profile across Bare Mountain, Crater Flat, and Yucca Mountain, Nevada: U.S. Geological Survey Open-File Report 95-834, 36 p.

Majer, E., Feighner, M., Johnson, L., Lee, K., Daley, T., Karageorgi, E., Parker, P., Smith, T., Williams, K., Romero, A., McEvilly, T., Ponce, D., Langenheim, V., 1996, Results of high-resolution geophysical surveys at Yucca Mountain: American Nuclear Society Proceedings of the 7th Annual International Conference on High Level Waste Management, v. 1, p. $151-154$.

Morelli, C.(Ed.), 1974, The International Gravity Standardization Net, 1971: International Association of Geodesy Special Publication no. 4, 194 p. (NNA.901127.0203)

Plouff, Donald, 1977, Preliminary documentation for a FORTRAN program to compute gravity terrain corrections based on topography digitized on a geographic grid: U.S. Geological Survey Open-File Report 77-535, 45 p. (NNA.901127.0204)

Ponce, D.A. 1993, Geophysical investigations of concealed faults near Yucca Mountain, southwest Nevada: American Nuclear Society Proceedings of the Fourth Annual International Conference on High Level Waste Management, v. 1, p. 168-174. (NNA.931025.0028)

Ponce, D.A., Langenheim, V.E., and Sikora, R.F., 1993, Gravity and magnetic data of Midway Valley, southwest Nevada: U.S. Geological Survey Open-File Report 93-540-A, documentation, 9 p, scale 1:12,000.; 93-540-B, diskette. (NNA.940418.0157) 
Ponce, D.A., and Langenheim, V.E., 1994, Preliminary gravity and magnetic models across Midway Valley and Yucca Wash, Yucca Mountain, Nevada: U.S. Geological Survey Open-File Report 94-572, 25 p.

Ponce, D.A., and Langenheim, V.E., 1995, Gravity and magnetic investigations of the Ghost Dance and Solitario Canyon faults, Yucca Mountain, Nevada: U.S. Geological Survey Open-File Report 95-521, 26 p.

Ponce, D.A., Sikora, R.F., Roberts, C.W., Morin, R.L., and Halvorson, P.F., 1995, Magnetic investigations along selected high-resolution seismic reflection traverses in the central block of Yucca Mountain, Nevada: U.S. Geological Survey Open-File Report 95-667, 23 p.

Rosenbaum, J.G., and Snyder, R.B., 1985, Preliminary interpretation of paleomagnetic and magnetic property data from drill holes USW G-1, G-2, G-3, and VH-1 and surface localities in the vicinity of Yucca Mountain, Nye County, Nevada: U.S. Geological Survey Open-File Report 85-49, 73 p.

Sawyer, D.A., Fleck, R.J., Lanphere, M.A., Warren, R.G., Broxton, D.E., and Hudson, M.R., 1994, Episodic caldera volcanism in the Miocene southwestern Nevada volcanic field: ${ }^{40} \mathrm{Ar} /{ }^{39} \mathrm{Ar}$ geochronologic framework and revised stratigraphy: Geological Society of America Bulletin, v. 106, p. 1304-1318.

Scott, R.B., and Bonk, Jerry, 1984, Preliminary geologic map of Yucca Mountain, Nye County, Nevada with geologic sections: U.S. Geological Survey Open-File Report 84494, scale 1:12,000. (HQS.880517.1443)

Spengler, R.W., Braun, C.A., Linden, R.M., Martin, L.G., Ross-Brown, D.M., and Blackburn, R.L., 1993, Structural Character of the Ghost Dance fault, Yucca Mountain, Nevada: American Nuclear Society Proceedings of the Fourth Annual International Conference on High level Waste Management, v. 1, p. 653-659.

Spengler, R.W., Braun, C.A., Martin, L.G., and Weisenberg, C.W., 1994, The Sundance fault: a newly recognized shear zone at Yucca Mountain, Nevada: U.S. Geological Survey Open-File Report 94-49, 11 p. (NNA.940128.0019)

Swick, C.A., 1942, Pendulum gravity measurements and isostatic reductions: U.S. Coast and Geodetic Survey Special Publication 232, 82 p. (NNA.901204.0008)

U.S. Geological Survey, 1979, Aeromagnetic map of the Timber Mountain area, Nevada: U.S. Geological Survey Open-File Report 79-587, scale 1:62,500, 3 sheets.

U.S. Geological Survey, 1984, A summary of geologic studies through January 1,1983, of a potential high-level radioactive waste repository site at Yucca Mountain, southern Nye County, Nevada: U.S. Geological Survey Open-File Report 84-792, 103 p. (N N A.891009.0305)

NOTE: Parenthesized numbers following each cited reference are for U.S. Department of Energy Office of Civilian Radioactive Waste Management Records Management purposes only and should not be used when ordering the publication. 
TA BLE 1.-Geologic names and symbols.

Modified from Sawyer and others (1994)

\begin{tabular}{|c|c|}
\hline Name of Unit & Symbol \\
\hline \multicolumn{2}{|l|}{ Quaternary } \\
\hline Alluvium and colluvium & Qac \\
\hline \multicolumn{2}{|l|}{ Miocene $^{1}$} \\
\hline Volcanics of Fortymile Canyon & Tfc \\
\hline Timber Mountain Group & \\
\hline Ammonia Tanks Tuff & Tma \\
\hline Rainier Mesa Tuff & $\mathrm{Tmr}$ \\
\hline tuff unit "X" & $\mathrm{Tmx}$ \\
\hline \multicolumn{2}{|l|}{ Paintbrush Group } \\
\hline Tiva Canyon Tuff & $\mathrm{Tpc}$ \\
\hline Yucca Mountain Tuff & Tpy \\
\hline Pah Canyon Tuff & $\mathrm{Tpp}$ \\
\hline Topopah Spring Tuff & $\mathrm{Tpt}$ \\
\hline Calico Hills Formation & Tht \\
\hline \multicolumn{2}{|l|}{ Crater Flat Group } \\
\hline Prow Pass Tuff & Tcp \\
\hline Bullfrog Tuff & $\mathrm{Tcb}$ \\
\hline Tram Tuff & Tct \\
\hline Lavas and Flow Breccias & T11 \\
\hline Lithic Ridge Tuff & Tlr \\
\hline Older Tuffs & $\mathrm{Tt}$ \\
\hline \multicolumn{2}{|l|}{ Paleozoic } \\
\hline Paleozoic rocks, undifferentiated & $\mathrm{Pz}$ \\
\hline
\end{tabular}

${ }^{1}$ Includes bedded tuff at base of most units 
TABLE 2.- Physical properties of rock units used in the models.

Values were derived from borehole samples, borehole logs, and surface samples ${ }^{1}$

\begin{tabular}{lrrrc}
\hline Unit & $\begin{array}{c}\text { Declination } \\
\text { deg }\end{array}$ & $\begin{array}{c}\text { Inclination } \\
\text { deg }\end{array}$ & $\begin{array}{c}\text { Magnetization } \\
\text { A }\end{array}$ & $\begin{array}{c}\text { Density } \\
\text { g/cm }\end{array}$ \\
\hline Qac & 0 & 0 & 0.0 & $1.5-1.8$ \\
Tfc & 170 & -30 & 1.9 & $1.8-2.0$ \\
Tma & 0 & 59 & 0.58 & 2.0 \\
Tm r & 168 & -55 & $0.8-2.7$ & $1.5-2.0$ \\
Tmx & 0 & 0 & 0.0 & 2.0 \\
Tpc & 169 & -23 & 0.94 & 2.0 \\
Tpy & 170 & 1 & 0.24 & 1.6 \\
Tpp & 154 & -62 & 1.6 & $1.4-1.9$ \\
Tpt & 322 & 52 & 1.3 & $2.2-2.4$ \\
Tht & 6 & 56 & 0.11 & $1.9-2.0$ \\
Tcp & -4 & 50 & 0.26 & $2.0-2.3$ \\
Tcb & 12 & 41 & 1.7 & $2.2-2.4$ \\
Tct & 131 & -30 & 1.2 & $2.0-2.4$ \\
Tll & 5 & 50 & 1.0 & 2.5 \\
Tlr & 251 & 62 & 0.22 & $2.0-2.4$ \\
Tt & 50 & 60 & 0.3 & 2.4 \\
Pz & 0 & 0 & 0.0 & 2.7 \\
\hline
\end{tabular}

1 Data modified from Rosenbaum and Snyder (1985), Bath and Jahren (1984), and M.R. Hudson (USGS, written commun., 1994)

2 Total declination, inclination, and magnetization

${ }^{3}$ Remanent declination, inclination, and magnetization 
Plate 1.-Location of central block traverses. Topographic contour interval $200 \mathrm{ft}$. Triangle, drill hole.

Plate 2.-Interpretive geophysical fault map of the central block of Yucca Mountain showing locations of all lines and magnetic anomaly profiles for only G1 through G4, YA through YE, AR, LYR, 3REG, JR1, JR2, 1, $3,4,7 \mathrm{a}, 8,9$, and 12 . Vertical scale for magnetic anomaly profiles, $400 \mathrm{nT} / \mathrm{in}$. Anomaly values increase to top for east-west profiles, anomaly values increase to right for north-south profiles. Red dots, prominent fault or prominent change in physical properties derived from ground magnetic data; Red circle, minor fault or minor change in physical properties derived from ground magnetic data; Blue dots, prominent fault or prominent change in physical properties inferred from gravity data; Blue circle, minor fault or minor change in physical properties inferred from gravity data; Green dots, fault or change in magnetization inferred from aeromagnetic data (U.S. Geological Survey, 1979); Red lines, prominent faults traceable from one profile to another based on gravity, ground magnetic, and aeromagnetic data; Triangle, drill hole; Gray lines, faults modified from Scott and Bonk (1984).

Plate 3.-Interpretive geophysical fault map of the central block of Yucca Mountain showing locations of all lines and magnetic profiles for remaining lines YF, 2REG, 2, 5, 6, 7, and 10 across the central block of Yucca Mountain. See plate 2 for explanation.

Plate 4.-Ground magnetic anomaly map derived from magnetic profiles across the central block of Yucca Mountain. Magnetic contour interval $20 \mathrm{nT}$. Width of swath $400 \mathrm{~m}$. See plate 2 for explanation. 


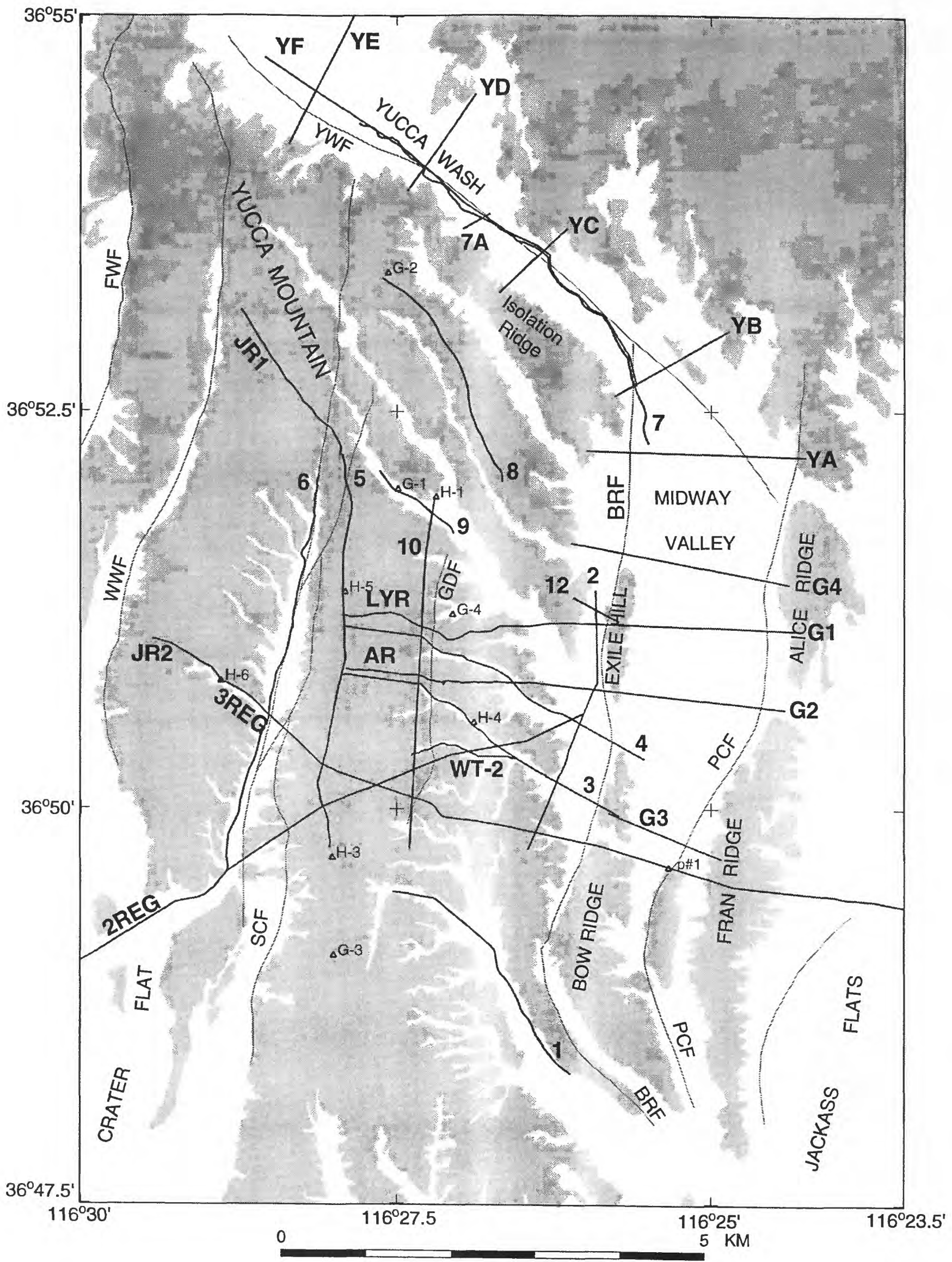

FIgURE 1.-Index map of the study area showing locations of magnetic profiles across the central block of Yucca Mountain. White area, Quaternary alluvium and colluvium; Shaded area, Tertiary volcanic rocks; Triangle, drill hole; BRF, Bow Ridge fault; FWF; Fatigue Wash fault; GDF, Ghost Dance fault; PCF, Paintbrush Canyon fault; SCF, Solitario Canyon fault; WWF, Windy Wash fault; YWF, Yucca Wash fault. Geology modified from Frizzell and Shulters (1990) and Scott and Bonk (1984). 
